Article

\title{
Corporate Social Responsibility and Insider Trading: Evidence from China
}

\author{
Chao Lu *, Xuetong Zhao and Jingwen Dai * \\ School of Economics and Management, Beijing Jiaotong University, Beijing 100044, China; 18125363@bjtu.edu.cn \\ * Correspondence: chaolu@bjtu.edu.cn (C.L.); 17120491@bjtu.edu.cn (J.D.)
}

Received: 30 July 2018; Accepted: 31 August 2018; Published: 4 September 2018

\begin{abstract}
Corporate Social Responsibility (CSR) is the obligation of a company to pursue long-term goals, and is an important part of a sustainable society. It is related not only to the survival and sustainable development of the company, but also to the expectations of the public. CSR is an important way for companies to disclose non-financial information. Information disclosure can alleviate information asymmetry effectively, improve the quality of internal control, and affect the occurrence of insider trading. However, the existing research has paid less attention to the impact of non-financial information on CSR and insider trading, as well as the impact of the corporate nature and disclosure motivation on this relationship. This paper takes China's 2011-2016 Shanghai and Shenzhen A-share listed companies as a sample to study the relationship between CSR and insider trading. The results show the following. (1) CSR and insider trading have a significant negative correlation. (2) From the perspective of the nature of the enterprise, the CSR of non-state-owned enterprises can significantly suppress the occurrence of insider trading, while the relationship is not significant for state-owned enterprises. (3) From the perspective of disclosure motivation, voluntary disclosure can significantly suppress the occurrence of insider trading. However, mandatory disclosure and semi-mandatory disclosure are not significant. The research in this paper is of great significance to encourage enterprises to fulfill their social responsibilities and improve the supervision of illegal insider trading.
\end{abstract}

Keywords: corporate social responsibility (CSR); insider trading; disclosure motivation

\section{Introduction}

In recent years, the growth of the capital market has been very fast, and the trading activities in the securities market have also shown a prosperous scene. Under the prosperous trading scene, there are also many unfair transactions that violate laws and regulations. Among them, one of the major activities related to many illegal cases is insider trading. Insider trading, which is also known as informed trading, refers to the act of leveraging the important information that is undisclosed by the enterprise that publicly issues the securities and can affect the price of the security through directly or indirectly using the information for securities trading [1]. At present, the attitude of China and most countries in the world to insider trading is that it is clearly prohibited, but insider trading still occurs frequently, and there is even more proliferation in some emerging markets. In 2015, general manager and others in China International Trust and Investment Corporation (CITIC) Securities were involved in insider trading investigations. In 2016, the chief financial officer (CFO) of Ecological Holdings Co., Ltd. (ENN) acquired three million in profit through insider trading. In 2017, three relatives were fined for insider trading because Mrs. Chairman's wife leaking reorganization information. In 2018, the deputy executive manager of the China Southern Power Grid was fined 5.21 million for insider trading. Frequent insider incidents have seriously damaged the principle of "fair, open, and just" in the securities market, which not only affects the interests of investors, but also attracts the attention 
of Chinese regulators. China has continuously strengthened its supervision over insider trading. According to statistics, as of 31 December 2017, the China Securities Regulatory Commission (CSRC) issued 236 penalties in total for insider trading events. From 2011, there have been 10, 14, 34, 46, 19, 57 , and 35 annual penalties, respectively. Thus, it can be seen that in recent years, the supervision of insider trading has been unstable, and insider trading may not be effectively suppressed. Since the current situation of frequent insider trading is hard to change in the short-term, and insider trading has great harm to the order of China's securities market, it is of great significance to study the influencing factors of insider trading and its control methods.

Although financial information can reflect the financial status and operating results of the company as a whole, much important information, except financial information, cannot be disclosed through traditional financial statements, and it is increasingly difficult to satisfy investors' accurate understanding of the company's operating status and the need to predict future performance. In the context of increasingly fierce commercial competition in recent years, Corporate Social Responsibility (CSR) has increasingly attracted the attention of various parties. Increasing the disclosure of non-financial information to improve investor decision-making and promote the sustainable development of enterprises has been widely recognized by the theoretical and practical circles [2,3]. CSR is the necessary way to safeguard the interests of corporate stakeholders and promote the sustainable development of society. According to existing research, CSR can be defined as the pursuit of social welfare maximization and sustainable development through the effective management and operation of enterprises to actively assume responsibility for society, stakeholders, and environmental protection [4-7]. CSR emphasizes that enterprises should set an example in protecting employees, consumers, and shareholders' rights, participating in environmental protection and social welfare, and taking responsibility for the sustainable and healthy development of the whole society [8]. Enterprises should not only pursue economic interests in strategic management and daily operations, but also be responsible for the public, stakeholders, and the natural environment, and create social value. From the perspective of enterprises, insider trading mainly occurs when there is an information asymmetry between insiders and ordinary investors in the market. When the company does not disclose information at all, the probability of insider trading within the company will be greatly enhanced. The non-financial information disclosure carried out by CSR can effectively alleviate the problem of information asymmetry [9], thereby curbing the occurrence of insider trading. In addition, CSR can change the internal environment of the enterprise and promote the quality and efficiency of the internal control of the enterprise. That is, enterprises with good CSR must have a perfect internal restraint mechanism [10], so as to effectively suppress the occurrence of insider trading.

In the past, research on the economic effects of CSR reports has mainly focused on the impact on corporate performance and value [11,12], stock prices [13,14], stock returns [15], etc., and generally classified the disclosure of CSR information into mandatory disclosure and voluntary disclosure at home and abroad. However, without involving semi-mandatory disclosure, there is a research gap [16-18]. Based on that, this paper takes 818 listed companies of Shanghai and Shenzhen A-shares in China from 2011-2016 years as samples, uses the multiple regression method of panel data with fixed effects, and distinguishes the motives of social responsibility report disclosure into mandatory disclosure, semi-mandatory disclosure, and voluntary disclosure. It then explores whether that social responsibility information can curb the occurrence of insider trading, as well as the impact of the corporate nature on this relationship. The research of this paper finds that CSR has a negative correlation with insider trading; that is, the higher the CSR, the more it can inhibit the occurrence of insider trading. Further research on the nature of the enterprise found that the negative correlation between CSR and insider trading in non-state-owned enterprises is particularly significant, while the mandatory disclosure and semi-mandatory disclosure are not significant. This indicates that when the disclosure motivation is different, the CSR report will produce quality differences; thus, its impact on insider trading is also different. 
The main contributions of this research are as follows. (1) This study will draw on domestic and foreign measurement methods of CSR, and deeply study whether different disclosure motives and CSR under the influence of corporate nature can play an active role in corporate governing and improve the transparency of corporate information, which in turn affects insider trading. It will then further explore the influencing factors and transmission mechanisms of insider trading, make up for the vacancies in past academic research, and improve the existing research system. (2) This paper divides the CSR report into mandatory disclosure, semi-mandatory disclosure, and voluntary disclosure. The classification of CSR report is more precise, and the addition of semi-mandatory disclosures is somewhat innovative. (3) Based on the empirical study of the relationship between CSR and insider trading, we comprehensively consider the impact of different disclosure motives and corporate nature on the relationship between CSR and insider trading. The research can fully reveal the impact mechanism between CSR and insider trading. Also, the results provide policy recommendations for improving the disclosure of CSR and the prevention and control of insider trading from a new perspective.

The rest of this paper is structured as follows. The second section reviews the related research on CSR and insider trading, and puts forward the hypothesis of this paper. The third section outlines the research design. The fourth section reports the empirical research results and the robustness test. The fifth and final section presents the conclusion and enlightenment.

\section{Literature Review and Research Hypothesis}

\subsection{CSR and Insider Trading}

Some scholars believe that non-financial information disclosure can alleviate information asymmetry and improve corporate transparency. Glosten and Milgrom used theoretical models to demonstrate that information disclosure can be used to alleviate information asymmetry [9]. Other studies have shown that companies with better financial performance tend to take on more CSR [19], and companies that value CSR are more likely to profit from economic activities [20]. Moreover, CSR helps to increase corporate value [21], but the role of CSR in corporate value may be influenced by investor sentiment [22]. In companies with high ownership concentration, the agency problem between management and major shareholders is very serious. Major shareholders need to compensate for the risk of participating in supervision and management activities, and management is more directly exposed to insider information than major shareholders, so management can use its information advantage to facilitate access to insider information and conduct insider trading to obtain excess returns. When major shareholders work hard to maximize their own interests, it is bound to harm the interest of external investors. The management can share insider information with the major shareholders; at this time, the major shareholders can compensate for the risks of participating in the supervision and management activities, and the management can also exempt the major shareholders from supervising them. In this way, major shareholders and managers collude with each other, share insider information, conduct insider trading, and ultimately harm the interests of external investors [23]. The disclosure of information by enterprises can alleviate the degree of information asymmetry between them, thus alleviating agency problems and improving the transparency of corporate information.

Internal control has become an important way for companies to improve their social responsibility and can effectively promote the standardized management of CSR [24]. Generally speaking, enterprises with a high quality of CSR have high internal control quality, and enterprises can effectively use external CSR to supervise and further improve the efficiency of internal supervision [10]. That is, the quality of internal control and CSR are mutually reinforcing and complement each other. In addition, according to signaling theory, managers who are motivated to pass on the high-quality signals of the company to the outside world are generally high-quality companies or companies with high internal control quality. They want to show external investors the value they owned. Sometimes, they will hire high-quality 
auditors with high salaries in order to improve the credibility of the company's information disclosure, hoping to influence investor decisions [25]. The companies with high internal control quality have a high quality of CSR. The internal control mechanism for management and other aspects will be more effective, and the probability of engaging in illegal insider trading will be lower.

Shleifer pointed out that the main influencing factor of insider trading behavior is corporate governance [26]. The insider trading of listed companies is largely caused by fragile corporate governance and internal control. Fragile corporate governance is prone to insider trading. Effective corporate governance can benefit listed companies in greatly improving the quality of information, while fragile corporate governance makes it difficult to provide good direction and guidelines for business management activities and form high-quality information. Companies with good corporate governance will have less insider trading, and at this time, the volume of trading and the degree of information asymmetry will be alleviated [27]. Among these influencing factors, the ownership structure [28,29], board characteristics, and executive compensation are internal factors, while institutional investors' shareholding [30], media supervision [31], securities analyst concerns [32], corporate mergers and acquisitions [33], and asset restructuring are external factors. The major shareholders of listed companies in China still have a high degree of control over the company. Compared with other investors, they have greater advantages in information, capital, and control, making it easier to conduct insider trading. The larger the board of directors of the listed company, the greater the probability of insider trading; that is, the change in the size of the board of directors will affect the efficiency of board supervision [34]. Noe found that executive compensation incentive contracts can significantly reduce the probability of the management conducting insider trading [35]. In addition, Keown and Pinkerton found that corporate mergers and acquisitions are often accompanied by serious insider trading, and insider informants have entered the market to obtain excess returns before the merger and acquisition (M\&A) news is first publicized [33].

Maffett found that executives generally obtain excess returns through insider trading when the company's financial information is opaque. This kind of insider trading behavior can be correspondingly reduced when the external environment is improved and corporates increase information disclosure and the transparency of their financial information [36]. Cui et al. found that although CSR is positively related to legal insider trading, higher levels of CSR can help reduce the probability of illegal and unethical insider trading. The environmental part of social responsibility has an especially significant negative relationship with insider trading [37]. The conclusion shows that CSR helps reduce a company's unfair and unethical illegal behavior, thereby improving economic efficiency and fairness. Gao et al. found that companies with higher CSR levels are less likely to engage in insider trading than companies with low CSR levels [38]. Kim et al. believed that CSR helps curb corporate earnings management activities and constrain the illegal behavior of management [16].

Based on the analysis above, we believe that information disclosure helps alleviate information asymmetry and improve agency problems, and according to signaling theory, firms with high internal control quality are willing to transmit good signals to the market. That is, firms with high-quality internal control have effective internal control restraint mechanisms, and thus a higher transparency of corporate information, and a lower probability of insider trading. So, the first hypothesis is proposed:

Hypothesis 1. There is a negative correlation between CSR and insider trading.

\subsection{CSR, Corporate Nature, and Insider Trading}

Huang et al. found that state-owned corporations disclose more CSR than other companies [39]. Due to the different ownership of state-owned enterprises and non-state-owned enterprises, their responsibilities and goals are not the same. For state-owned enterprises, their CSR has been concerned by many parties, and the public's expectations for state-owned enterprises are generally higher [40]. These are determined by the nature of the enterprises. Bolívar et al. found that the 
major shareholders of state-owned enterprises pay more attention to the improvement of CSR through empirical research [41]. This is because the large shareholders of state-owned enterprises should pay attention to the medium and long-term development of enterprises based on the perspective of compliance management and profit. Aside from economic interests, they should also consider social responsibility. Due to the nature of the company, it is clear that there is a big gap between the degree of government intervention and the expectation of the public from state-owned and non-state enterprises. In summary, the CSR of listed companies in China's state-owned enterprises is higher in quality than non-state enterprises, and its impact on insider trading should be greater.

Investors often view information or news in the market that has not been seen by the public, and is not fully and timely disclosed, as bad news. At this time, some companies with good performance usually take the initiative of information disclosure, which conveys the company's high-quality signals to avoid being treated as "lemon". Due to its own strength, a poorly performing company cannot disclose such high-quality information and imitate this disclosure. The disclosure of CSR-related information by non-state enterprises is obviously weaker than that of state-owned enterprises; that is, high-quality companies usually voluntarily disclose information. At the same time, compared with state-owned enterprises, non-state enterprises will have stronger strategic philanthropic needs based on economic motivation, which will help improve the quality of their social responsibility.

In summary, both state-owned and non-state-owned enterprises have their own advantages and disadvantages in information disclosure. The quality of disclosure will also vary with consideration. We cannot decide which one is "better". So far, we raise the two competitive hypothesis:

Hypothesis 2A. In state-owned enterprises, the negative correlation between CSR and insider trading is more significant than that in non-state enterprises.

Hypothesis 2B. In non-state enterprises, the negative correlation between CSR and insider trading is more significant that in state-owned enterprises.

\subsection{CSR, Disclosure Motivation, and Insider Trading}

Based on the existing institutional background, this study divides the disclosure motivation of corporate social responsibility into three categories: mandatory disclosure, semi-mandatory disclosure, and voluntary disclosure. In China, the problem of illegal information disclosure is serious, and the level of voluntary disclosure is low. The traditional mandatory information disclosure is closer to a legal concept. It advocates the government to regulate the information disclosure of listed companies. Under this model, listed companies must disclose non-financial information according to the content and methods of relevant regulations, and bear the corresponding legal responsibilities. The purpose of the compulsory disclosure system is to try to ensure the disclosure quality of listed companies' information through standardized and legal information disclosure methods, so as to promote the openness and transparency of information in the securities market and alleviate information asymmetry.

The paper categorizes the disclosure of the social responsibility information of central enterprises as semi-mandatory disclosure. The fulfillment of social responsibility by central enterprises is not only to satisfy the expectations and requirements of stakeholders and the public; it also increasingly becomes an important way to achieve the sustainable development of the company, improve the management level of central enterprises, foster competitive advantages, and positively affect the company's image. Nearly $70 \%$ of central enterprises choose to publish social responsibility reports and become models for fulfilling social responsibility. In addition, the senior executives of central enterprises tend to choose to publish social responsibility reports for the consideration of promotion. The central enterprises are a relatively special group that are affiliated with the State-owned Assets Supervision and Administration Commission of the State Council (SASAC), and are the backbone and pillar of the state-owned economy. 
In addition to undertaking their due economic responsibilities, the central enterprises also bear more social and political responsibilities. In January 2008, the SASAC issued a document about The Guidance for the Central Enterprises to Disclose Their Social Responsibilities Information, clearly stating that "the central enterprises must strengthen their sense of social responsibility, [and] actively carry out their social responsibilities", which encourages central enterprises to issue social responsibility reports voluntarily. In fact, the leaders of the central enterprises respond positively to the SASAC's call for their reputation and promotion, and generally choose to publish social responsibility reports voluntarily. On the whole, central enterprises mainly choose to disclose social responsibility information under the guidance of existing rules. Due to its special state-owned status and responsibility for economic, political, and social aspects, the disclosure motivation of central enterprises lies between compulsory and voluntary disclosure. Relatively speaking, semi-mandatory disclosure information will lack timeliness and regularity, and the proportion of voluntary certification is relatively low.

In summary, due to different disclosure motives, the CSR reports of mandatory disclosure, semi-mandatory disclosure, and voluntary disclosure will be different in quality, and the trait information contained in the report will also be different. They will also have different impacts on insider trading. Based on this, the third hypothesis of this paper is proposed:

Hypothesis 3. Under the situation of all other conditions being equal, the CSR report will produce quality differences while the disclosure motivation is different, and thus also have different impacts on insider trading.

\section{Empirical Study Design}

\subsection{Sample Description and Data Resource}

This paper selects all of China A-share listed companies from 2011 to 2016 as the initial sample, and conducts the following screening treatments. (1) As we intend to examine the characteristics and financial indicators of financial companies, we eliminate finance companies. (2) To prevent considering a single enterprise that conducts insider trading several times in the same year as multiple events, we regard the same major asset reorganization events of the same company on the first announcement date as the same event. (3) In order to avoid the interaction between different events, we eliminate the samples that the initial announcement interval was less than 180 days for the same company. (4) Only the first event is selected as the research sample when the same enterprise has more than one major asset reorganization event in the same year. Finally, the effective sample of this paper is 818 listed companies, and contains a total of 3362 samples. The CSR report rating score is from the RANKINS CSR RATINGS (RKS) database. The enterprise data and major asset restricting events are classified from China Stock Market Trading Database (CSMAR). In order to alleviate the influence of outliers (the maximum and the minimum) on parameter estimation, this paper will perform the tailing adjusting (Winsorize) on the continuous explanatory variable CSR ratings, and the tailing adjustments are in the first and 99th of its distribution, respectively.

\subsection{Definition of Main Variables}

\subsubsection{Insider Trading}

This study uses the major asset restructuring information that has not been disclosed by listed companies as the insider information, since major asset restructuring is usually a process of reorganizing, adjusting, and arranging the distribution of corporate assets, or reconfiguring the rights set on corporate assets. Compared with performance growth and high distribution, major asset reorganization is the proprietary information of insiders of listed companies. In companies with information disclosure specifications, such information will only be conquered slightly through normal professional technical analysis. Therefore, all of the major securities markets will list merge 
major enterprises as insider information. Based on that, it is appropriate to select the major asset restructuring event to measure insider trading.

Keown and Pinkerton found in research that corporate mergers and acquisitions are often accompanied with serious insider trading behavior [33]. Insider informants have entered the market to obtain excess returns before the M\&A news was publicized. John and Lang [42] also found that before the company's dividend announcement was issued, insiders had already acquired excess returns with existing information. Li et al. used 19 consecutive years as sample data from 1998 to 2016, and concluded that nearly $70 \%$ of the inside information of the investigated cases belonged to the merger and acquisition, which fully proved that the probability of insider trading in mergers and reorganization was extremely high [43]. Based on this, we adjusted the measurement method of insider trading, and introduced the dummy variable INSTRAD into the model. When the listed company has major asset reorganization behavior, we considered it as generating insider information, and then marked it as 1 . For the companies that had not conducted insider trading, we marked them as 0 . In addition, in order to avoid endogeneity, this paper will be explained by a one-year lag; that is, the explanatory variables and control variables are the values of the previous year corresponding to the insider trading.

\subsubsection{Corporate Social Responsibility}

This study uses the listed company's disclosure of CSR report motivation, corporate nature, and CSR rating to measure CSR information.

The reference point of CSR is taken from McGuinness [44]; we use RKS as a measure. The data in RKS is gained by its own evaluation system for listed companies. The scores obtained from the evaluation can directly measure the disclosure of CSR information. The companies with higher ratings own better CSR.

\subsubsection{CSR Disclosure Motivation}

We divide the corporate disclosure motivation into three categories. In December 2008, the CSRC requested the Shanghai Stock Exchange (SSE) "SSE Corporate Governance Sector", the issuance of overseas listed foreign shares and financial companies, and the listed companies of the Shenzhen Stock Exchange "Shenzhen 100 Index" disclose social responsibility reports mandatorily, so these four categories are defined as a mandatory disclosure of a social responsibility report. Central-governmental enterprises, which are the main enterprises of the state-owned economy, play an irreplaceable role in supporting, guiding, and promoting economic and social development. The regular publication of social responsibility reports has become the consensus of central enterprises. Based on this, we defined the companies in which the ultimate control lies with the central enterprise of the state-owned assets supervision and Administration Commission under the State Council as having semi-mandatory disclosure. Then, we defined the others as having a voluntary disclosure of social responsibility report.

\subsubsection{Control Variables}

Control variables are generally variables that complement the explanatory variables and affect the variable being interpreted. Based on the existing research at home and abroad, and combined with the actual situation of listed companies in China, this paper will select Rate of Return on Assets (ROA), Ownership Concentration (SHARE), the proportion of Independent Directors (OUTSIDER), Enterprise Growth (GROWTH), and the dummy variable of year and industry as control variables in this paper. The metric method of the main variable in this study is shown in Table 1. 
Table 1. Main variables.

\begin{tabular}{|c|c|c|c|}
\hline Category & Variable & Symbol & Variable Definitions \\
\hline Dependent Variable & Insider trading & INSTRAD & $\begin{array}{l}\text { Insider trading is marked as } 1 \text {, the other is } \\
\text { marked as } 0 .\end{array}$ \\
\hline Independent Variable & $\begin{array}{l}\text { Corporate } \\
\text { social responsibility }\end{array}$ & CSR & RKS \\
\hline Control Variable & Rate of Return on Assets & ROA & NET INCOME/AVERAGE ASSET \\
\hline Control Variable & $\begin{array}{l}\text { Ownership } \\
\text { Concentration }\end{array}$ & SHARE & $\begin{array}{l}\text { Total stockholding of the first major } \\
\text { shareholders/equity }\end{array}$ \\
\hline Control Variable & $\begin{array}{l}\text { The proportion of } \\
\text { Independent Directors }\end{array}$ & OUTSIDER & $\begin{array}{l}\text { Number of independent directors/total number } \\
\text { of directors }\end{array}$ \\
\hline Control Variable & Enterprise Growth & GROWTH & $\begin{array}{l}\text { (Operating income-operating income of the } \\
\text { previous year)/operating income of the } \\
\text { previous year }\end{array}$ \\
\hline
\end{tabular}

\subsection{Empirical Model}

Based on the key indicators, we establish the logit model for each hypothesis, and then use an empirical test to analyze. In this paper, we use STATA12 for regressions.

$$
\operatorname{INSTRAD~}_{i, t}=\beta_{0}+\beta_{1} \times \operatorname{CSR}_{i, t-1}+\gamma \times \text { ControlVariable }_{i, t-1}+\varepsilon_{i, t}
$$

Insider trading is measured by 0 and $1 . C S R_{i, t-1}$ represents lag CSR. The impact of insider trading has hysteresis, because the CSR reports are usually published the next year. In addition, our regression considered year and industry fixed effects. If the Hypothesis 1 is established, the signal of coefficient $\beta_{1}$ is significantly negative.

We divide the nature of enterprises into state-owned enterprises and non-state-owned enterprises, and then we repeat the operation in Hypothesis 1. If Hypothesis 2A is established, then the absolute value of the coefficient of state-owned enterprises will be greater than that of non-state-owned enterprises. Otherwise, If Hypothesis 2B is established the coefficient of state-owned enterprises is significant and the coefficient of non-state-owned enterprises is not significant. Another assumption is the opposite.

We divide the disclosure motivation into three categories: mandatory disclosure, semi-mandatory disclosure, and mandatory disclosure, and still operate as in Hypothesis 1. Then, we analyze the result the same as in Hypothesis 2.

\section{Results and Discussion}

\subsection{Descriptive Statistics}

Based on the data collected from the database, we conducted a descriptive statistical analysis of all of the sample data. As can be seen from Table 2, in the mean test of 3362 sample data, the average CSR score for the five years from 2011 to 2015 is lower at 40.4934, indicating that the overall quality of social responsibility of Chinese enterprises is poor. It is also directly related to the late start of China's CSR and imperfect development. The standard deviation is 12.8664 , which indicates that there are big differences between the CSR of different enterprises in China, and these may have certain links with the nature of the enterprise, corporate culture, and corporate development goals. The minimum rating of CSR score is 15.1152 , the maximum is 89.2979 , and the standard deviation is 74.1827 , which shows that the dispersion of CSR is large. This is also fully reflected in the other control variables below. The standard deviation of the share ratio of the first largest shareholder and the growth rate of the main business is slightly larger than the other variables. This indicates that there are some differences between the variables in different companies, especially regarding the main business of the enterprise. Its growth rate has a mean of 0.0080 and a median of 0.0009 , indicating that the growth of the company 
is very different in different companies. To sum up, the average value of each variable is within the normal range, which also reflects the sufficient sample size from the side, and indicates that the research is credible.

Table 2. Descriptive statistic.

\begin{tabular}{ccccccc}
\hline Variable & Mean & Median & Max & Min & Standard Deviation & N \\
\hline CSR & 40.4934 & 37.3292 & 89.2979 & 15.1152 & 12.6184 & 3362 \\
ROA & 0.0424 & 0.0343 & 2.1103 & -0.6907 & 0.0683 & 3362 \\
OUTSIDER & 0.3745 & 0.3636 & 0.8000 & 0.1818 & 0.0595 & 3360 \\
SHARE & 0.3672 & 0.3549 & 0.8635 & 0.0022 & 0.1654 & 3362 \\
GROWTH & 0.0080 & 0.0009 & 9.6134 & -0.4720 & 0.1697 & 3360 \\
\hline
\end{tabular}

After creating the descriptive statistics of the overall sample, we made descriptive statistics on the overall sample group by group. One of the research hypotheses of this paper is to explore the impact of the nature of the enterprise on the relationship between CSR and insider trading. Therefore, we have redivided the total research sample into groups according to state-owned enterprises and non-state-owned enterprises, and analyzed them descriptively. As can be seen from Table 3, in the mean test, there is a big difference between state-owned enterprises and non-state-owned enterprises. The average CSR of state-owned enterprises is 42.0715 , while the average CSR of non-state-owned enterprises is 37.7685. This shows that the quality of the CSR of state-owned enterprises is much higher than that of non-state-owned enterprises. Comparing their standard deviations, we can find that the standard deviation of the CSR ratings of state-owned enterprises is higher than that of non-state-owned enterprises. The sample size of state-owned enterprises is 2129 , and the sample size of non-state-owned enterprises is 1233. The information above indicates that the proportion of state-owned enterprises that publish CSR reports is higher than that of non-state-owned enterprises, but the quality of their disclosures is uneven. The higher mean of the CSR ratings of state-owned enterprises may also be because state-owned enterprises disclose more CSR information, and the number is large, so as the base is large, which may increase the overall average.

Table 3. Descriptive statistics of state-owned enterprises and non-state-owned enterprises.

\begin{tabular}{|c|c|c|c|c|c|c|c|c|c|c|}
\hline \multirow[b]{2}{*}{ Variable } & \multicolumn{5}{|c|}{ State-Owned Enterprise } & \multicolumn{5}{|c|}{ Non-State-Owned Enterprise } \\
\hline & Mean & Max & Min & $\begin{array}{l}\text { Standard } \\
\text { Deviation }\end{array}$ & $\mathbf{N}$ & Mean & Max & Min & $\begin{array}{l}\text { Standard } \\
\text { Deviation }\end{array}$ & $\mathbf{N}$ \\
\hline CSR & 42.0715 & 88.8481 & 15.1152 & 13.2453 & 2129 & 37.7685 & 89.2979 & 15.6521 & 10.9368 & 1233 \\
\hline ROA & 0.0337 & 0.3894 & -0.6907 & 0.0583 & 2129 & 0.0576 & 2.1103 & -0.2929 & 0.0807 & 1233 \\
\hline OUTSIDER & 0.3742 & 0.8000 & 0.1818 & 0.0605 & 2127 & 0.3751 & 0.6000 & 0.1818 & 0.0578 & 1233 \\
\hline SHARE & 0.3983 & 0.8635 & 0.0022 & 0.1672 & 2129 & 0.3136 & 0.7889 & 0.0223 & 0.1477 & 1233 \\
\hline GROWTH & 0.0047 & 0.5082 & -0.0472 & 0.0233 & 2129 & 0.0138 & 9.6135 & -0.0243 & 0.2786 & 1231 \\
\hline
\end{tabular}

Comparing the control variables, we can find that the concentration of ownership of state-owned enterprises is higher, while the return on assets of non-state-owned enterprises is higher, as is the growth of their enterprises. This may be due to the mature stage of state-owned enterprises. In contrast, non-state-owned enterprises are still in comparative stages of development and growth, with greater space for growth and development, and they will pay more attention to the development indicators of the company.

In summary, there are significant differences in CSR and corporate characteristics between state-owned enterprises and non-state-owned enterprises, and the impact on insider trading will certainly be different. 


\subsection{Correlation Analysis}

Table 4 mainly reports the correlation coefficient of the main variables: the Pearson correlation coefficient in the lower left corner, and the Spearman correlation coefficient in the upper right corner. From the correlation analysis results, the two indicators of INSTRAD and CSR showed good consistency at the $10 \%$ level, which shows that CSR has a significant negative correlation with insider trading within univariate influencing factors. We can also meet the expectations of hypothesis H1 initially.

Table 4. Correlation test.

\begin{tabular}{ccccccc}
\hline & INSTRAD & CSR & ROA & OUTSIDER & SHARE & GROWTH \\
\hline INSTRAD & & $-0.0160^{*}$ & $-0.0473^{* * *}$ & 0.0159 & $-0.0458^{* * *}$ & $0.0263^{* * *}$ \\
CSR & $-0.0249^{*}$ & & $-0.0305^{* *}$ & 0.0056 & $0.0993^{* * *}$ & -0.0913 \\
ROA & $-0.0560^{* * *}$ & $-0.0404^{* *}$ & & -0.0273 & 0.0430 & 0.0116 \\
OUTSIDER & $0.0266^{* * *}$ & $0.0160^{* * *}$ & -0.0168 & & $0.0733^{* * *}$ & $0.0639^{* * *}$ \\
SHARE & $-0.0450^{* * *}$ & $0.1311^{* * *}$ & 0.0280 & $0.0905^{* * *}$ & & -0.0494 \\
GROWTH & $0.2708^{* * *}$ & -0.0216 & -0.0031 & $0.0728^{* * *}$ & -0.0090 & \\
\hline
\end{tabular}

Notes: The statistics in brackets are $\mathrm{z}$ statistics. ${ }^{* * *},{ }^{* *}$, and ${ }^{*}$ denote statistical significance at the $1 \%, 5 \%$, and $10 \%$ levels, respectively.

\subsection{Regression Analysis}

\subsubsection{CSR and Insider Trading}

According to the results of the Hausman test, this paper finally selected the fixed effect model. It can be seen from Table 5 that the coefficient of CSR is 0.0154 , and the significance level is $5 \%$; that is, there is a significant negative correlation between CSR and insider trading. It can be proved that $\mathrm{H} 1$ is established.

Table 5. CSR and insider trading.

\begin{tabular}{|c|c|c|c|}
\hline & \multirow{2}{*}{ All Samples } & \multicolumn{2}{|c|}{ The Nature of Enterprises } \\
\hline & & (State-Owned Enterprise) & (Non-State-Owned Enterprise) \\
\hline \multirow{2}{*}{ CSR } & $-0.0154^{* *}$ & -0.0098 & $-0.0229 *$ \\
\hline & $(-2.17)$ & $(-1.13)$ & $(-1.76)$ \\
\hline \multirow{2}{*}{ ROA } & $-3.0124^{* * *}$ & $-3.9525^{* * *}$ & -1.8510 \\
\hline & $(-2.72)$ & $(-3.05)$ & $(-0.86)$ \\
\hline \multirow{2}{*}{ OUTSIDER } & 1.7033 & 1.8397 & 1.0558 \\
\hline & $(1.36)$ & $(1.14)$ & $(0.53)$ \\
\hline \multirow{2}{*}{ SHARE } & $-1.1861 * *$ & -0.9289 & $-1.3690 *$ \\
\hline & $(-2.40)$ & $(-1.47)$ & $(-1.67)$ \\
\hline \multirow{2}{*}{ GROWTH } & 0.6891 & -1.5226 & 0.9668 \\
\hline & $(0.84)$ & $(-0.25)$ & $(0.51)$ \\
\hline INDUSTRY & yes & yes & yes \\
\hline YEAR & yes & yes & yes \\
\hline Prob > chi2 & 0.0000 & 0.0001 & 0.0000 \\
\hline Pseudo R2 & 0.0525 & 0.0407 & 0.0798 \\
\hline $\mathrm{N}$ & 3358 & 2127 & 1231 \\
\hline
\end{tabular}

Notes: The statistics in brackets are $\mathrm{z}$ statistics. ${ }^{* * *},{ }^{* *}$, and ${ }^{*}$ denote statistical significance at the $1 \%, 5 \%$, and $10 \%$ levels, respectively. The $\mathrm{N}$ is the sample observations.

The release of CSR reports by a company is generally derived from two elements. The first is internal factors, which include the need for business self-development. In the process of continuous development and growth, enterprises will gradually realize the importance of comprehensive information disclosure. The release of CSR is a very important channel for information disclosure. All stakeholders and investors can have a more comprehensive understanding of the development of 
the company in addition to financial indicators, and a more comprehensive and in-depth grasp of the status quo of the enterprise publishing its CSR, according to the company. The other element includes the external factors; that is, stakeholders expect to see the results of such a report form a comprehensive understanding of the development of each company. At present, enterprises that publish CSR are mainly central enterprises and listed companies. The CSR report can provide stakeholders with a systematic summary of the specific social responsibility of the enterprise, and is also conducive to the promotion of corporate culture. Also, CSR can help companies disseminate excellent responsibility concepts internally, increase the transparency of information between companies and stakeholders, enhance corporate reputation, and provide key information to external investors' investment decisions.

The root of agency problems is that shareholders cannot always supervise management. Management may try to do something that harms the interests of shareholders for the sake of maximizing their own interests. Although insider trading can alleviate the conflict of interest between management and shareholders caused by different fundamental economic goals, it also deepens the conflict of interest between major shareholders and external shareholders, and even generates a serious asymmetry information problem. When information asymmetry occurs, the party that has more information in the transaction will have an advantage, and the possibility of profiting from the transaction will increase. From the perspective of enterprises and stakeholders, considering the separation of the two powers, enterprises will disclosure more CSR information and also have more undisclosed information than stakeholders. At this time, stakeholders obtaining information requires extra cost to fill in this piece of undisclosed information. If the company actively discloses CSR information, the stakeholders can self-interpret the important information that they need based on the disclosed information, thereby forming an estimate of the future development prospects of the enterprise, or combining other known news to help. Make judgments on your own. CSR disclosure is also a process of transmitting corporate information to the market. This initiative also helps companies form a good corporate reputation.

Companies with higher CSR ratings will have a higher level of comprehensive development not only in terms of financial indicators, but also regarding the impact of the company on society and the role of demonstration. Companies with higher CSR ratings will possess stronger corporate social credibility, as well as higher information transparency, and the culture and responsibility concept will be better in the enterprise. Under the guidance of this mainstream trend, the illegal operation of insider trading will also subject to a certain degree of inhibition. In addition, a company with the quality of corporate social responsibility reflects that the company has good internal control, indicating that the internal constraint mechanism is perfect, and accordingly, the probability of management and other illegal insider trading events will also decrease.

Next, we focus on the control variables. As can be seen from Tables 4 and 5, the coefficient of return on assets is -3.0124 , and it is significant at the significance level of $1 \%$, which indicates that a company with a better financial performance will also have a better internal governance of the enterprise, and could suppress the occurrence of illegal insider trading. The probability of insider trading will decrease. The coefficient of the shareholding ratio of the largest shareholder is -1.1861 , and it is significant at the level of $5 \%$ significance, which confirms the relationship between equity concentration and insider trading. That is, if a company has a higher concentration of equity, the major shareholders in it will be more motivated to supervise the company, and insider trading can be suppressed.

These results are similar to the research of Maffett [36]. Opportunities for executives to obtain excess returns through insider trading are generally generated when the company's financial information is opaque. This kind of insider trading behavior can be correspondingly reduced while the external environment is improved; corporates increase information disclosure, and increase the transparency of financial information. Moreover, Cui et al. also found the same result: CSR had a positive relationship with legal insider trading, and CSR had a negative relationship with illegal insider trading [37]. 


\subsubsection{CSR, Corporate Nature, and Insider Trading}

From the results in Table 5, we can also compare the impact of the nature of enterprises on the relationship between CSR and insider trading. We have carried out logit regression on CSR and insider trading in state-owned enterprises and non-state-owned enterprises. Comparing the regression results, we can see that the total number of state-owned enterprise disclosure social responsibility reports is nearly twice that of non-state owned enterprises, and in state-owned enterprises, there is no significant correlation between CSR and insider trading. However, in non-state-owned enterprises, the regression coefficient of CSR is -0.0229 , and the significant level is $10 \%$; that is, the negative correlation between CSR and insider trading of non-state-owned enterprises is more significant, which proves that $\mathrm{H} 2 \mathrm{~B}$ is established.

In China, ordinary investors cannot accurately understand the actual operation of the company. In the market, when some information is not disclosed in the public's field in a timely manner and is instead controlled by investors, it is very likely to be used by investors. This signifies that a company is a "lemon", which is bad news in the traditional sense. At the same time, in order to prevent being treated as "lemon", some well-developed companies hope to disclose the information to the market to pass on the good signal of their own business. Most of the non-state-owned enterprises are like this. They usually receive less supervision and attention than the state-owned enterprises, and they can only continuously strengthen their own strengths and strive to take more responsibility. They show their value and get more favor from outsider investors. They improve the quality of CSR in order to form a better corporate culture and learn more excellent responsibility concepts. Thereby, they reduce the probability of illegal insider trading, and incur less violations. Relatively speaking, state-owned enterprises have developed to a more mature stage, and their internal staff will certainly increase their demand for excess profits. At the same time, this does not conflict with the high CSR ratings. Having developed too maturely may have led to a mature and independent division system in various departments of the enterprise, which means that the social responsibility of the enterprise and the insider trading system for obtaining excess returns have been separated, and the information in different departmental systems cannot affect each other. The excellent corporate responsibility concept has been unable to have a significant inhibitory effect on illegal behavior.

\subsubsection{CSR, Disclosure Motivation, and Insider Trading}

As can be seen from Table 6, the impact of different disclosure motives on the relationship between CSR and insider trading is also very different. Based on the existing institutional background, this study divides CSR disclosure into mandatory disclosure, semi-mandatory disclosure, and voluntary disclosure.

At present, there are serious non-compliance problems in China's domestic information disclosure, and the overall voluntary disclosure level is very low. Voluntary disclosure is closer to an incentive system. When an insider has this information advantage, he needs to pass this information to the market in order to improve his competitive advantage. News in the market that has not been seen by the public, that is, information that is not disclosed fully in time, is often viewed as bad news by investors. At this time, some companies with good performance usually take the initiative information disclosure to convey the company's high-quality signals to avoid being mistaken for a "lemon". A poorly performing company, due to its own strength, cannot disclose such high-quality information and cannot imitate the disclosure operation. Mandatory information disclosure is more akin to a legal regulation; it relies mainly on the government's compulsory intervention power to unify the norms. The purpose of mandatory disclosure is to ensure the quality of the information disclosure of enterprises through standardized and legal information disclosure systems, which in turn helps the open and transparent securities market and helps alleviate information asymmetry. The innovative point of this paper is that it adds the method of dividing the disclosure motive, which is based on the original disclosure motive division, and defines the behavior of the central enterprise to issue the CSR report as semi-mandatory disclosure (if the central enterprise has mandatory disclosure, it is still classified in the mandatory disclosure classification. The public's expectation of the central enterprise 
to fulfill its social responsibility is generally higher than that of other enterprises, and this is also conducive to the central enterprises to improve their own management level, create a better corporate image, and pave the way for the company to achieve sustainable development.

Table 6. CSR and insider trading (disclosure motivation).

\begin{tabular}{cccc}
\hline & \multicolumn{3}{c}{ Disclosure Motivation } \\
\cline { 2 - 4 } & Mandatory & Semi-Mandatory & Voluntary \\
\hline CSR & -0.0105 & 0.0271 & $-0.0247^{*}$ \\
& $(-1.14)$ & $(1.07)$ & $(-1.69)$ \\
ROA & $-5.3594^{* * *}$ & -4.0717 & -0.8854 \\
& $(-2.70)$ & $(-0.99)$ & $(-0.60)$ \\
OUTSIDER & 0.4002 & -1.1039 & 2.6488 \\
& $(0.20)$ & $(-0.20)$ & $(1.44)$ \\
SHARE & -0.2454 & 1.7650 & $-2.5460 * *$ \\
& $(-0.34)$ & $(0.90)$ & $(-3.21)$ \\
GROWTH & -0.7805 & -2.5324 & 0.6849 \\
& $(-0.24)$ & $(-0.26)$ & $(0.80)$ \\
INDUSTRY & yes & Yes & yes \\
YEAR & yes & yes & yes \\
Prob $>$ chi2 & 0.0141 & 0.5092 & 0.0000 \\
Pseudo R2 & 0.0320 & 0.0730 & 1182 \\
N & 2014 & 162 & 0.094 \\
\hline
\end{tabular}

Notes: The statistics in brackets are $\mathrm{z}$ statistics. ${ }^{* * *},{ }^{* *}$, and ${ }^{*}$ denote statistical significance at the $1 \%, 5 \%$, and $10 \%$ levels, respectively. The $\mathrm{N}$ is the sample observations.

According to the results shown in the Table 6, CSR has a significant negative correlation with insider trading, which is only under the motive of voluntary disclosure. This indicates that the quality of CSR reports from different disclosure motives is indeed different. The trait information contained in the report is also different, which has different effects on insider trading. So, Hypothesis 3 is established.

At present, only the voluntary disclosure of CSR has the most significant impact on insider trading, indicating that CSR reports that contain mandatory disclosure and semi-mandatory disclosure do co-exist with the phenomenon of taking advantage of undue gains. In such instances, the company passively releases a CSR report with poor quality. The trait information contained is weak, which fails to effectively suppress the occurrence of insider trading.

\subsection{Robustness Test}

This study utilizes the robustness test to test the robustness of this research. After taking an observation of the five-year corporate social responsibility report from 2011 to 2015 comprehensively, we found that every company's CSR ratings have increased or decreased every year, and that they are also constantly fluctuating, which may be due to some of the internal responsibility concepts having changed. At the same time, the degree of information asymmetry and the information that enterprises transmit to the market will change, as will the impact on insider trading. Companies that are doing well are also more inclined to disclose more corporate social responsibility. Enterprises expect that they will not be able to conduct insider trading this year, but the market has not yet received this news, so they will be very serious when dealing with corporate social responsibility. Therefore, the analysis above may have a reverse causal relationship. Then, the CSR ratings of the previous year in the empirical study will be used to replace the CSR ratings of the year to alleviate the possible reverse causal relationship mentioned above.

The results show that the conclusions of this study are still valid for $\mathrm{H} 1$ and $\mathrm{H} 2$, while $\mathrm{H} 3$ cannot be proved. The robustness test results in Table 7 show that the coefficient of CSR in the full sample is negative and significant, which indicates that $\mathrm{H} 1$ is established. There is a negative correlation between 
CSR and insider trading, since CSR can inhibit corporate irregularities and improve information transparency. Besides, in non-state-owned enterprises, the negative correlation between CSR and insider trading is more significant than that in state-owned enterprises, which proves that $\mathrm{H} 2 \mathrm{~B}$ is established. Non-state-owned enterprises gain market competitiveness by actively undertaking CSR to reduce insider trading and other irregularities, while state-owned enterprises are relatively mature in their operation and management and less involved in insider trading. At this time, the inhibition of CSR on insider trading is not significant enough in state-owned enterprises. The robustness test results in Table 8 show that the coefficients of CSR are not significant; that is, when the disclosure motivation is distinguished, there is no significant difference in the impact of CSR on insider trading, which is inconsistent with H3. This may be because there is no obvious time lag effect in the disclosure motivation, and the disclosure motivation can affect the quality of the CSR report issued by the enterprise in time, and then act on insider trading. However, in the robustness test, CSR with a one-year lag is used to test $\mathrm{H} 3$, which may be the reason why $\mathrm{H} 3$ has not been proven.

Table 7. Robustness test (1).

\begin{tabular}{|c|c|c|c|}
\hline & \multirow{2}{*}{ All Samples } & \multicolumn{2}{|c|}{ The Nature of Enterprises } \\
\hline & & (State-Owned Enterprise) & (Non-State-Owned Enterprise) \\
\hline CSR & $\begin{array}{l}-0.0163 \text { ** } \\
(-2.35)\end{array}$ & $\begin{array}{l}-0.0126 \\
(-1.42)\end{array}$ & $\begin{array}{c}-0.0195^{*} \\
(-1.78)\end{array}$ \\
\hline ROA & $\begin{array}{l}-3.4020 * * * \\
(-3.09)\end{array}$ & $\begin{aligned}- & 4.3171 * * * \\
& (-3.20)\end{aligned}$ & $\begin{array}{l}-2.3690 \\
(-1.59)\end{array}$ \\
\hline OUTSIDER & $\begin{array}{c}2.1686^{*} \\
(1.83)\end{array}$ & $\begin{array}{c}2.3746 \\
(1.50)\end{array}$ & $\begin{array}{c}2.0941 \\
(1.14)\end{array}$ \\
\hline SHARE & $\begin{array}{c}-0.8450 * \\
(-1.77)\end{array}$ & $\begin{array}{l}-0.6908 \\
(-1.09)\end{array}$ & $\begin{array}{l}-0.3910 \\
(-0.50)\end{array}$ \\
\hline GROWTH & $\begin{array}{l}-0.1397 \\
(-0.26)\end{array}$ & $\begin{array}{l}6.2036^{* *} \\
(2.46)\end{array}$ & $\begin{array}{l}-3.2085 \\
(-1.14)\end{array}$ \\
\hline $\begin{array}{l}\text { INDUSTRY } \\
\text { YEAR }\end{array}$ & $\begin{array}{l}\text { yes } \\
\text { yes }\end{array}$ & $\begin{array}{l}\text { yes } \\
\text { yes }\end{array}$ & $\begin{array}{l}\text { yes } \\
\text { yes }\end{array}$ \\
\hline Prob > chi2 & 0.0000 & 0.0000 & 0.0217 \\
\hline Pseudo R2 & 0.0356 & 0.0501 & 0.0312 \\
\hline $\mathrm{N}$ & 3358 & 2127 & 1231 \\
\hline
\end{tabular}

Notes: The statistics in brackets are $\mathrm{z}$ statistics. ${ }^{* * *},{ }^{* *}$, and ${ }^{*}$ denote statistical significance at the $1 \%, 5 \%$, and $10 \%$ levels, respectively. The $\mathrm{N}$ is the sample observations.

Table 8. Robustness test (2).

\begin{tabular}{cccc}
\hline & \multicolumn{3}{c}{ Disclosure Motivation } \\
\cline { 2 - 4 } & Mandatory & Semi-Mandatory & Voluntary \\
\hline CSR & -0.0085 & 0.0255 & -0.0203 \\
& $(-0.93)$ & $(0.96)$ & $(-1.48)$ \\
ROA & $-3.8501 *$ & $-11.0421 * *$ & -1.8529 \\
& $(-1.92)$ & $(-2.38)$ & $(-1.31)$ \\
OUTSIDER & 2.1148 & -2.1879 & 2.2906 \\
& $(1.18)$ & $(-0.45)$ & $(1.31)$ \\
SHARE & -0.4906 & 2.5349 & $-1.3889 * *$ \\
& $(-0.67)$ & $(1.24)$ & $(-1.96)$ \\
GROWTH & $6.7678 * *$ & -3.4532 & -2.3320 \\
& $(2.30)$ & $(-0.33)$ & $(-0.31)$ \\
INDUSTRY & yes & yes & yes \\
YEAR & yes & yes & yes \\
Prob $>$ chi2 & 0.0373 & 0.1573 & 0.0001 \\
Pseudo R2 & 0.0275 & 0.1206 & 0.05063 \\
N & 2014 & 162 & 1182 \\
\hline
\end{tabular}

Notes: The statistics in brackets are $z$ statistics. ${ }^{* * *}, * *$, and ${ }^{*}$ denote statistical significance at the $1 \%, 5 \%$, and $10 \%$ levels, respectively. The $\mathrm{N}$ is the sample observations. 


\section{Conclusions}

This paper takes the insider trading of China's A-share listed companies from 2012 to 2016 and the CSR report of China's A-share listed companies from 2011 to 2015 as the research samples (the samples rejected in the study have been accounted for in the sample selection). Then, it empirically studied the impact of CSR of listed companies on insider trading. The study found that CSR has a significant negative impact on insider trading. That is to say, the information disclosure of CSR alleviates the problem of information asymmetry and inhibits the occurrence of insider trading. Moreover, there are quality differences in the corporate social responsibility reports of different companies, and the effect of suppressing illegal insider trading is also very different. Companies with higher social corporate responsibility ratings will have a stronger social credibility of the enterprise. Companies with higher information transparency within their enterprise will own better corporate culture and responsibility concepts. Then, the illegal operations of insider trading will also correspond. At the same time, companies with higher CSR ratings will own higher qualities of internal control. When the companies own more complete internal restraint mechanisms, the probability of illegal insider trading by management will be lower. The negative impact of CSR on insider trading is more significant. The voluntary disclosure of CSR companies has a negative impact on CSR over other disclosure motives. Insider trading will aggravate the problem of information asymmetry in the market, undermine the market's fair and healthy trading environment, and seriously damage the interests of investors. After this research, it can be known that the disclosure of CSR can effectively curb the occurrence of illegal insider trading, which provides a new direction for the supervision of domestic trading. That is, we should vigorously promote the disclosure of China's CSR reports and increase the enterprise's information transparency, as it allows companies to accept public scrutiny. Companies ought to make full use of CSR reports to transmit positive and excellent signals to the market, improve their corporate reputation, optimize corporate responsibility concepts, and accept the supervision of stakeholders and the public. At the same time, this practice relieves the serious agency problems within the enterprise and further reduces the problem of information asymmetry. However, the CSR reports of state-owned enterprises have an unsatisfactory effect on the suppression of insider trading, indicating that some state-owned enterprises have experienced the phenomenon of taking advantage of undue gains in the disclosure of CSR. Relevant laws, regulations, and policies should be introduced to restrict the quality of social responsibility reports. At present, the voluntary disclosure of corporate social responsibility reports has the best inhibitory effect on insider trading. The government can continue to encourage enterprises to make voluntary disclosures and actively transmit signal information to the market. The information on the securities market is disordered, which is not conductive to more accurate judgments by stakeholders. Some companies that perfuse disclosure and report quality will decrease market efficiency. As the leaders of the country, the central enterprises should play an exemplary role in promoting the quality of their own social responsibilities, not just to meet the policy requirements, but also to inculcate the corporate responsibility concept and inject a positive example into the securities market. The vitality of the wind reduces the occurrence of non-compliance within the company itself, and is strict with self-discipline, leading Chinese enterprises to build a more active and healthy securities trading market.

Although our research contributes to the CSR and insider trading literature in multiple ways, there are still some limitations in this study. This paper uses CSR rating as a measure of CSR, and there is an original rating system in RKS rating that conducts a comprehensive evaluation of CSR reports, which consists of first-level indicators and second-level indicators. The classification can be considered the direction for future study. For example, we can continue to explore specific indicators such as governance transparency information, risk management information, and the environment, and consider whether they have an impact on insider trading and if so, what kind of impact they have. They can provide more detailed and targeted suggestions for insider trading regulations. Future study can also be taken to observe the impact of CSR on insider trading under China's institutional background over a longer period of time. 
Author Contributions: The manuscript was written with the contributions of all authors. C.L. presents themes and key research hypotheses, writes the first draft with J.D., and deal with the problems in the paper. J.D. conceived the theoretical part, designed empirical research and revised the paper. X.Z. take a lot of effort in the introduction, data collection, and formatting of papers.

Funding: This paper is supported by Fundamental Funds for Humanities and Social Sciences of Beijing Jiaotong University (2018JBW006).

Conflicts of Interest: The authors declare no conflict of interest.

\section{References}

1. Beneish, M.D.; Vargus, M.E. Insider Trading, Earnings Quality, and Accrual Mispricing. Account. Rev. 2002, 77, 755-791. [CrossRef]

2. Kim, Y.; Li, H.; Li, S. Corporate Social Responsibility and Stock Price Crash Risk. J. Bank. Financ. 2014, 6, 1-13. [CrossRef]

3. Jha, A.; Cox, J. Corporate Social Responsibility and Social Capital. J. Bank. Financ. 2015, 60, $252-270$. [CrossRef]

4. Wood, D.J. Corporate Social Performance Revisited. Acad. Manag. Rev. 1991, 16, 691-718. [CrossRef]

5. Clarkson, M.E. A Stakeholder Framework for Analyzing and Evaluating Corporate Social Performance. Acad. Manag. Rev. 1995, 20, 92-117. [CrossRef]

6. Carroll, A. A Three-dimensional Conceptual Model of Corporate Performance. Acad. Manag. Rev. 1979, 4, 497-505. [CrossRef]

7. Garriga, E.; Melé, D. Corporate Social Responsibility Theories: Mapping the Territory. J. Bus. Ethics 2004, 53, 51-71. [CrossRef]

8. Dutordoir, M.; Strong, N.; Sun, P. Corporate Social Responsibility and Seasoned Equity Offerings. J. Corp. Financ. 2018, 50, 158-179. [CrossRef]

9. Glosten, L.R.; Milgrom, P.R. Bid, Ask and Transaction Prices in a Specialist Market with Heterogeneously Informed Traders. J. Financ. Econ. 1983, 14, 71-100. [CrossRef]

10. Wang, J. Corporate Social Responsibility and Internal Control: Interactive Relationship and Optimization Path Research. Commun. Financ. Account. 2012, 3, 13-15.

11. Gherghina, S.C.; Simionescu, L.N. Does Entrepreneurship and Corporate Social Responsibility Act as Catalyst towards Firm Performance and Brand Value? Int. J. Econ. Financ. 2015, 7, 23-34. [CrossRef]

12. Singh, P.; Sethuraman, K.; Lam, J. Impact of Corporate Social Responsibility Dimensions on Firm Value: Some Evidence from Hong Kong and China. Sustainability 2017, 9, 1532. [CrossRef]

13. Rodriguez, P.; Siegel, D.S.; Hillman, S.; Eden, L. Three Lenses on the Multinational Enterprise: Politics, Corruption, and Corporate Social Responsibility. J. Int. Bus. Stud. 2006, 37, 733-746. [CrossRef]

14. Barnea, A.; Heinkel, R.; Kraus, A. Corporate Social Responsibility, Stock Prices, and Tax Policy. Can. J. Econ./Revue Canadienne D'économique 2013, 46, 1066-1084. [CrossRef]

15. Guidry, R.P.; Patten, D.M. Market Reactions the First-time Issuance of Corporate Sustainability Reports. Sustain. Account. Manag. Policy J. 2010, 1, 33-50. [CrossRef]

16. Kim, Y.; Park, M.S.; Wier, B. Is Earnings Quality Associated with Corporate Social Responsibility? Account. Rev. 2012, 87, 761-796. [CrossRef]

17. Dhaliwal, D.; Li, O.; Tsang, A.; Yang, Y. Voluntary Non-financial Disclosure and the Cost of Equity Capital: The Initiation of Corporate Social Responsibility Reporting. Account. Rev. 2011, 86, 59-100. [CrossRef]

18. Hu, Y.M.; Tan, Y.C. Non-financial Information Disclosure: Literature Review and Future Prospects. Account. Res. 2013, 3, 20-26, 95.

19. Sial, M.S.; Zheng, C.; Khuong, N.V.; Khan, T.; Usman, M. Does Firm Performance Influence Corporate Social Responsibility Reporting of Chinese Listed Companies? Sustainability 2018, 10, 2217. [CrossRef]

20. Hategan, C.-D.; Sirghi, N.; Curea-Pitorac, R.-I.; Hategan, V.-P. Doing Well or Doing Good: The Relationship between Corporate Social Responsibility and Profit in Romanian Companies. Sustainability 2018, $10,1041$. [CrossRef]

21. Miralles-Quirós, M.M.; Miralles-Quirós, J.L.; Valente Gonçalves, L.M. The Value Relevance of Environmental, Social, and Governance Performance: The Brazilian Case. Sustainability 2018, 10, 574. [CrossRef] 
22. Eom, K.; Nam, G. Effect of Entry into Socially Responsible Investment Index on Cost of Equity and Firm Value. Sustainability 2017, 9, 717. [CrossRef]

23. Maug, E. Insider Trading Legislation and Corporate Governance. Eur. Econ. Rev. 2002, 46, 1569-1597. [CrossRef]

24. Hao, D.Y.; Qi, G.Y.; Wang, J. Corporate Social Responsibility, Internal Controls, and Stock Price Crash Risk: The Chinese Stock Market. Sustainability 2018, 10, 1675. [CrossRef]

25. Ashbaugh-Skaife, H.; Collins, D.W.; Kinney, W.R., Jr. The Discovery and Reporting of Internal Control Deficiencies Prior to SOX-mandated Audits. J. Account. Econ. 2007, 44, 166-192. [CrossRef]

26. Shleifer, A.; Vishny, R.W. A Survey of Corporate Governance. J. Financ. 1997, 52, 737-783. [CrossRef]

27. Rozanov, K.A. Corporate Governance and Insider Trading; Massachusetts Institute of Technology: Cambridge, MA, USA, 2008.

28. Grossman, S.J. The Informational Role of Warranties and Private Disclosure about Product Quality. J. Law Econ. 1981, 24, 461-483. [CrossRef]

29. Jensen, M.C.; Meckling, W.H. Theory of the Firm: Management Behavior, Agency Cost and Ownership Structure. J. Financ. Econ. 1976, 3, 305-360. [CrossRef]

30. Dennis, P.J.; Strickland, D. Who Blinks in Volatile Markets, Individuals or Institutions? J. Financ. 2002, 57, 1923-1950. [CrossRef]

31. McCombs, M.E.; Shaw, D.L. The agenda-setting function of mass media. Public Opin. Q. 1972, 36, $176-187$. [CrossRef]

32. Lang, M.H.; Lins, K.V.; Miller, D.P. Concentrated Control, Analyst Following, and Valuation: Do Analysts Matter Most When Investors Are Protected Least? J. Account. Res. 2004, 42, 589-623. [CrossRef]

33. Keown, A.J.; Pinkerton, J.M. Merger Announcements and Insider Trading Activity: An Empirical Investigation. J. Financ. 1981, 36, 855-869. [CrossRef]

34. Cao, T.Q. Ownership Structure, Corporate Characteristics and Scale of Boards of Directors!in Listed Companies. J. Shandong Univ. 2007, 3, 12.

35. Noe, H.T. Insider Trading and the Problem of Corporate Agency. J. Law Econ. Organ. 1997, 13, $287-318$. [CrossRef]

36. Maffett, M. Financial Reporting Opacity and Informed Trading by International Institutional Investors. J. Account. Econ. 2012, 54, 201-220. [CrossRef]

37. Cui, J.; Jo, H.; Li, Y. Corporate Social Responsibility and Insider Trading. J. Bus. Ethics 2015, 130, 869-887. [CrossRef]

38. Gao, F.; Lisic, L.L.; Zhang, I. Commitment to Social Good and Insider Trading. J. Account. Econ. 2014, 57, 149-175. [CrossRef]

39. Huang, Q.H.; Peng, H.G.; Zhong, H.; Zhang, E. Evaluating the Level of Responsibility Management and CSR Information Disclosure of Top 100 Companies in China. China Ind. Econ. 2009, 29, 23-35.

40. Qiao, M.Z.; Liu, F.C. A Study of Chinese State-owned Enterprises' CSR on Perspective of Nature and Function. East China Econ. Manag. 2010, 3, 86-90.

41. Bolívar, M.P.R.; Sánchez, R.G.; Hernández, A.M.L. Managers as Drivers of CSR in State-owned Enterprises. J. Environ. Plan. Manag. 2015, 58, 777-801. [CrossRef]

42. John, K.; Lang, L.H.P. Insider Trading around Dividend Announcements: Theory and Evidence. J. Financ. 1991, 46, 1361-1389. [CrossRef]

43. Li, S.X.; Tang, Y.P. Characteristics of Insider Trading Cases and Supervision Defects in China-Reflections on Legal Cases from 1998 to 2016. J. Shanghai Univ. (Soc. Sci. Ed.) 2018, 1, 107-120.

44. McGuinness, B.P.; Vieito, J.P.; Wang, M. The Role of Board Gender and Foreign Ownership in the CSR Performance of Chinese Listed Firms. J. Corp. Financ. 2017, 42, 75-99. [CrossRef]

(C) 2018 by the authors. Licensee MDPI, Basel, Switzerland. This article is an open access article distributed under the terms and conditions of the Creative Commons Attribution (CC BY) license (http:/ / creativecommons.org/licenses/by/4.0/). 